\title{
Chapter 7 \\ The Linkage Between Monetary and Financial Stability: Some Policy Perspectives
}

\author{
Solikin M. Juhro
}

\begin{abstract}
Since the onset of the GFC, issues concerning financial stability have become as important as those on monetary stability. A key question regarding their nexus: are the two mutually supportive or do they work against each other in the sense of a trade-off? This chapter explores background issues on the linkages between monetary and financial stability from central bank policy perspectives. It explores some technical aspects of implementation and implications, especially concerning the central bank's mandate.
\end{abstract}

Keywords Monetary stability $\cdot$ Financial stability $•$ Macro-financial linkage • Policy mix

\section{Preview of Monetary Stability and the Financial Stability Nexus}

Discussion of issues concerning financial stability becomes as important as monetary the issues of monetary stability since the onset of the global financial crisis of 2008/09 (GFC). There is a variety of definitions related to monetary and financial stability. The broadly accepted definition of monetary stability in academic circles and for the central bank is a condition that guarantees the attainment of price stability as defined by low, stable prices (subdued inflation). The factual basis for this lies in the important role that price changes play in the process of adjustments and decision-making by economic agents. However, a clear understanding of financial stability is missing due to the absence of agreement on a definition. In this respect, Mishkin (1990) defines financial stability as a condition in which the financial sector guarantees efficient allocation of savings and investment in a sustainable manner and without significant disruption, but this definition is considered too broad. A more easily discernible definition is used in analysis, in which financial stability is a situation marked by stable asset prices and the absence of banking crises, with market interest forces

S. M. Juhro (西)

Bank Indonesia, Jakarta, Indonesia 
transmitted readily into interest rates (Issing 2003). In this paper, financial stability is understood more in line with the latter definition.

Given the definitions of monetary stability and financial stability, there is a question regarding their nexus: are the two mutually supportive (complementary) or do they work against each other (substitute) in the sense of a trade-off? The conventional view is that monetary stability supports financial stability. Nevertheless, the main proponents of this view regard monetary or price stability as more of a 'sufficient condition' for financial stability (Schwartz 1995). This view assumes that inflation is one of the main factors behind financial market instability. A related opinion is that inflation increases the likelihood of misperceptions concerning future income achievement and exacerbates the problem of asymmetric information between lenders and borrowers. In another view, high inflation also encourages high price fluctuations, which create business uncertainty and even banking crises.

This argument is consistent with the reverse relationship, in which a banking crisis will trigger monetary instability. In this respect, a twin crisis involving the banking system and the exchange rate will cause an unexpected or even reversed monetary policy impact (Goldfajn and Gupta 2002). In a crisis involving only the exchange rate, tight monetary policy has the potential to stabilise the exchange rate, prompt a reversal through changes in the nominal exchange rate and stabilise the financial sector. However, in a banking crisis, the opposite will occur, whereby a tight monetary policy stance will reduce the probability of a reversal. In this situation, several factors will influence the monetary policy response, such as the extent of the currency mismatch at domestic banks and the discretionary powers of the central bank in supplying liquidity in a crisis situation. ${ }^{1}$ The difference in the nature of the relationship during different crises is in accordance with the conventional view that there is generally no trade-off between monetary stability and financial stability.

The 'new environment' hypothesis, however, suggests such a trade-off based on the proposition that successful inflation control by the central bank could foster overly optimistic market perceptions and forecasts for the future of the economy. Incorrect perceptions create a false sense of security and lead to miscalculations of asset values with possible future negative impact. Borio et al. (2001) indicates that the combination of increased asset prices, high economic growth and low inflation within the context of a stabilisation programme could foster exaggerated expectations of future economic performance. Overoptimistic expectations could lead to drastically escalating activity on the asset and credit markets that surpasses the level of potential productivity improvement. This in turn drives up asset prices and fuels a booming trend along with inflationary pressures. At this stage, there is little empirical evidence to support such a proposition.

Issing (2003) analyses the trade-off by taking into account the time horizon to ascertain whether the trade-off is short term or long term. In this respect, the tradeoff possibly arises in the short term, during a period of sudden disinflation (inflation

\footnotetext{
${ }^{1}$ As transpired in Indonesia, the complexity of problems during the twin crises in 1997/98 undermined the effectiveness of monetary policy responses. This was reflected not only in high interest rates, but also massive liquidity flows.
} 
below the predicted rate). In the 'new environment', this could precipitate fragility because of its effect on driving down nominal interest rates, which further exacerbates moral hazard in the form of increased high-risk lending in a low interest, low inflation environment. In some cases, in a very low inflationary environment, this opens the possibility to an asset price bubble. However, the fragility in the disinflation period will tend to be short-lived. Not only will the economy adjust itself to the low inflationary environment, but the central bank is also likely to raise nominal interest rates to curb inflation of asset prices caused by excessive investment and in so doing prevent long-term inflationary pressure and any resultant economic crisis. Thus, within the context of the forward-looking central bank mandate of building price stability with a view to the horizon (medium and long term), this conflict will disappear of its own accord. ${ }^{2}$

In subsequent discussions, especially at the onset of the global financial crisis of 2008/09, Borio and Zhu (2008) put forward the existence of the 'risk-taking channel' and suggest three mechanisms to explain this new channel. The first relates to valuation factors, income and cash flows. Under this mechanism a decline in interest rates would increase the evaluation perception on asset prices and profit potential. In this context, a decline in interest rates is parallel to the perception of a rise in profit potential and cash flow. What emerges from this behaviour is a rise in risk-taking behaviour by economic players when the monetary policy stance is loose. The second mechanism corresponds to the correlation between interest rates and the target (nominal) rates of return. This mechanism is in line with the assumption that a decline in interest rates would increase the money illusion towards asset ownership attributable to a sticky rate of return. Similar to the first mechanism, this will subsequently encourage risk-taking behaviour. The last mechanism relates to the positive effect of transparency from central banks. In this respect, greater transparency or central bank commitment would reduce future uncertainty and lower the risk premium, consequently improving risk-taking behaviour.

Some empirical studies support the argument of a risk-taking channel in the monetary policy transmission mechanism. Altunbas et al. (2009), for instance, find evidence that unusually low interest rates over an extended period of time cause an increase in banks' risk taking, although further analysis is required concerning to what extent monetary policy or the general level of interest rates is significant for the banks' risk-taking. De Nicolo et al. (2010) also suggest that monetary policy easing will increase risk taking but this relationship depends on the health of the banking system, i.e. less so for poorly capitalized banks. These findings bear on the policy debate on how to integrate the monetary and macroprudential policy framework to meet the dual objectives of monetary stability (price) and financial stability. This issue becomes particularly relevant in the future, given the fact that the nexus

\footnotetext{
${ }^{2}$ From another standpoint, because of the threat posed by financial instability to inflation stability in the medium and long term, the price stability focus of central bank actions must consider financial stability. The implication of possible short-term conflict certainly does not overrule the conventional wisdom that price stability promotes financial stability.
} 
between monetary and financial stability, whether they are substitutes or complements, will depend on the types of shocks to the economy as well as the role of portfolio effects and risk shifting that force the banks' condition.

This paper explores background issues on the linkages between monetary and financial stability from central banking policy perspectives. The following section presents financial sector behaviour and monetary policy effectiveness, touching mainly upon financial sector characteristics that could potentially exacerbate macroeconomic instability by developing output fluctuations (procyclicality) and their implication on the workings of monetary policy. The third section elaborates the need to integrate the monetary and financial system stability framework, including the implementation of macroprudential policy in several countries. The fourth section provides the policy instrument mix as a key strategy to implement the monetary and financial system stability framework. It elaborates objectives and policy mix variations, as well as explores some technical aspects of implementation. The last section derives conclusions and implications, especially concerning the adjustment of the central bank's mandate and its consequences on policy governance.

\section{Financial Sector Behaviour and Monetary Policy Effectiveness}

The previous section posed the importance of the financial system for the monetary policy transmission mechanism, implying the need for the central bank to better understand the linkages between the financial sector and monetary policy. This issue has become increasingly pronounced, especially since the Global Financial Crisis of 2008/09. The crisis provided a key lesson that the financial sector plays a crucial role in macroeconomic stability because of its behaviour that triggers excessive procyclicality. ${ }^{3}$ Due to its procyclical nature, the financial sector could potentially compound macroeconomic instability by amplifying output fluctuations. The procyclical characteristic of the financial sector is inherently attributable to a number of factors. Firstly, asymmetric information in the financial market that triggers the financial accelerator. With this kind of market characteristic, when the economy is in a contractionary period and collateral values are low, even a sound corporation with a profitable project would find it difficult to access credit. Conversely, when economic conditions improve and collateral values increase, the same corporation would regain access to banks, thereby adding to economic stimuli. Although the financial accelerator is the main mechanism behind the occurrence of procyclicality, disproportional responses of market players in perceiving risks also contribute to the worsening of procyclicality (Borio et al. 2001).

\footnotetext{
${ }^{3}$ Procyclicality is defined as a character of the financial sector that follows economic activity. Through the work of the financial accelerator, it further pushes an economy to grow faster when in a cycle of expansion and weaken during a period of contraction.
} 
Table 7.1 Interaction between the business cycle, risk behaviour and the financial cycle

\begin{tabular}{l|l|l|l}
\hline & Business cycle & Risk-taking cycle & Financial cycle \\
\hline Expansionary phase & $\begin{array}{l}\text { Macroeconomic } \\
\text { stability } \\
\text { Increased economic } \\
\text { growth }\end{array}$ & $\begin{array}{l}\text { Confidence and } \\
\text { Optimism up } \\
\text { Risk-taking up } \\
\text { Credit demand up }\end{array}$ & $\begin{array}{l}\text { Risk value down, } \\
\text { interest rate spread } \\
\text { narrower } \\
\text { Asset prices up, pushing } \\
\text { up collateral value } \\
\text { Leverage up } \\
\text { Foreign capital inflows } \\
\text { up } \\
\text { Credit extension up }\end{array}$ \\
\hline Contractionary phase & $\begin{array}{l}\text { Heightened macro } \\
\text { volatility } \\
\text { Decreased economic } \\
\text { activity }\end{array}$ & $\begin{array}{l}\text { Market confidence } \\
\text { down } \\
\text { Risk averse } \\
\text { Credit demand } \\
\text { down }\end{array}$ & $\begin{array}{l}\text { Bank deleveraging } \\
\text { Loan loss provisions up } \\
\text { Interest rate spread } \\
\text { wider } \\
\text { Credit extension down } \\
\text { Capital inflows down }\end{array}$ \\
\hline
\end{tabular}

Source Nijathaworn (2009), edited

Procyclicality is not just the result of interactions between the business cycle and financial cycle; it is also affected by the risk-taking cycle, which is a characteristic marked by over-optimism during economic booms and over-pessimism in times of economic bust (Nijathaworn 2009). The interaction of the three can typically be described in the context of a boom-bust cycle. Initially, when the economy moves during an expansionary phase, characterised by macroeconomic stability and escalating growth, investor confidence raises optimism when assessing the economy. This will lead to the risk-taking behaviour, which will eventually push up credit demand and asset prices (Table 7.1).

During this optimistic period, risk in the financial sector eases, lending rate spread narrows and risky asset allocation is reduced as banks prefer to apply a shortterm perspective to a longer-term one. Surging asset prices push collateral values up thereby boosting credit expansion. This further improves market confidence and encourages risk-taking behaviour, reflected by soaring leverage. Greater credit expansion compels corporations to boost investment and households to raise consumption, further lifting economic growth. Conversely, when confidence in the economy dwindles, investors become risk averse. As a result, asset prices drop, causing collateral values to fall. Banks respond by deleveraging, shifting their portfolio from high-risk credit to low-risk assets, such as central bank certificates and government bonds, in a bid to maintain capital adequacy. Reserve allocation is also expanded to anticipate deteriorating credit quality. Such conditions undermine credit expansion, which, in turn, harms the economy.

Secondly, procyclicality may also emerge in line with the characteristics of financial sector regulations, which are inherently procyclical. For instance, the rules on capital and provisioning determine a softer requirement on banks during a period of economic boom or expansionary phase. One of the rules governing the banking 
sector that is deemed procyclical is Basel II. Basel II specifically aims to strengthen risk management at banks. However, it also poses a procyclical impact as the Basel II Framework indirectly encourages banks not to accumulate additional capital while banking and economic conditions are prospective, and to raise capital when such conditions deteriorate. Consequently, in the event of a crisis, banks are required to increase their capital ratio, but they are forced to seek funding in a limited capacity, which may further worsen the banks' condition. In addition, the Internal Rating Based approach under Basel II demands that capital requirements be based on a bank's estimation on the possibility of default of its loans and related losses, as both tend to increase during a crisis period. This may exacerbate the impact of a crisis on credit supply and the economy overall.

Furthermore, accounting standards are suspected of contributing to procyclicality. According to accounting standards that assess a bank's balance sheet components on the basis of the market value approach, if the economic situation is improving, the value of the assets or the performance of banks will also be considered improving so that banks are not required to have a high capital requirement and provision. In such a situation, banks are inclined to make expansive moves. However, in the event of a crisis or during a contractionary period, asset value would fall but the bank would not be able to use its capital or risk provisions immediately to maintain balance sheet conditions. This would subsequently lead to worsening conditions and potentially pose systemic risk in the banking sector.

Empirically, procyclicality can be observed through the development of bank credit during both expansionary and contractionary periods. Observable correlations between average credit growth and economic growth indicate that the higher the economic growth is, the higher the average credit growth would be. Moreover, credit growth was observed to outpace GDP growth during an expansionary period and grow slower during an economic downturn. Table 7.2 presents procyclicality in several Asian countries measured by the correlation coefficient of GDP and real credit.

The complexity of problems accompanying procyclical behaviour in the financial sector ultimately takes its toll on the efficacy of the monetary policy transmission mechanism. Mishkin (2009) stated that monetary policies potentially tend to be more

Table 7.2 Procyclicality of real credit and GDP in several Asian countries

\begin{tabular}{l|l}
\hline Countries & Correlation coefficients \\
\hline Indonesia & 0.82 \\
\hline Malaysia & 0.51 \\
\hline Philippines & 0.33 \\
\hline Thailand & 0.32 \\
\hline Australia & 0.26 \\
\hline Japan & 0.48 \\
\hline China & 0.31 \\
\hline Hong Kong SAR & 0.30
\end{tabular}

Source Craig et al. (2006) 


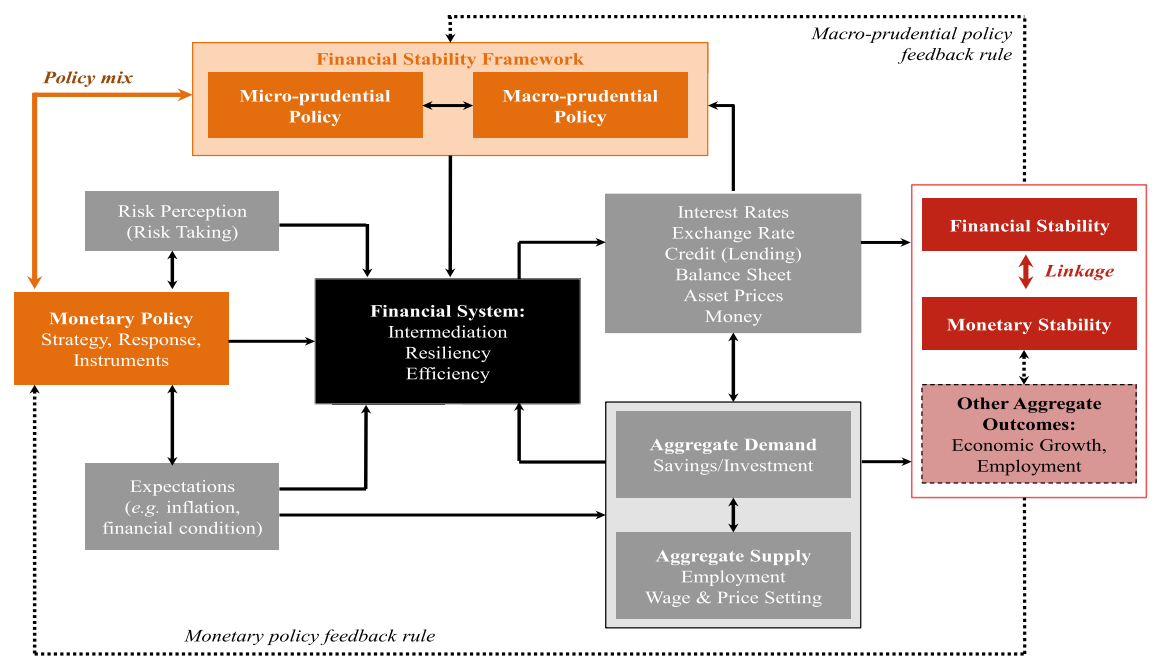

Fig. 7.1 Monetary-financial stability linkages and the monetary policy transmission mechanism. Source Bank Indonesia

efficient during economic crises rather than during normal times, thereby providing a basis to carry out macroeconomic risk management to deal with the problems related to economic contraction during times of crisis. This statement shows a link between monetary stability and financial sector stability. ${ }^{4}$ Some empirical observations support the close correlation between financial sector behaviour and the monetary policy transmission mechanism. Nier and Zicchino (2008) discovered that bank credit supply is affected by monetary policy stance that interacts with balance sheet stress and is then transmitted through bank losses. They concluded that the repercussions of interaction between the monetary policy stance and bank losses grow stronger during a crisis period, assuming that the magnitude of financial sector risk will escalate in the case of an economic crisis.

Figure 7.1 describes the workings of the transmission mechanism in the presence of risk perception (risk taking). When the economy experiences an expansionary phase, characterized by macroeconomic stability and escalating growth, investor confidence raises optimism when assessing the economy. Such risk-taking behaviour, which is initially triggered by monetary policy, will eventually drive up credit demand and asset prices. Changes in the financial sector, as reflected in adjustments of financial variables (financial stability), influence aggregate outcomes such as economic growth and employment, which are directly linked to monetary

\footnotetext{
${ }^{4}$ As mentioned in the early part of this section, Borio and Zhu (2008) explain the importance of the risk-taking channel within the monetary policy transmission mechanism. The risk-taking channel, in contrast to the financial accelerator concept discussed by Bernanke and Gertler (1999), affects bank credit supply through the banks' decision to extend credit in accordance with the banks' behavioural changes to credit risk. In connection with this, empirical studies have provided sufficient evidence of the existence of the risk-taking channel within the monetary policy transmission mechanism.
} 
stability. This is where the linkage between financial stability and monetary stability occurs. A healthy macroeconomic environment and monetary stability has bidirectional feedback with financial system stability. Any developments between monetary and financial stability will be considered by monetary policymakers through the macro-prudential policy feedback rule, which is scrutinised under the financial stability framework.

Within this policy perspective, in order to strengthen the framework of monetary and financial system stability, the central bank must be more flexible and creative when responding to emerging uncertainties within the economy and to think beyond public perception. Such flexibility is not only linked to the adjustment preference to control inflation and manage the macroeconomy on the one hand, and the role of financial system stability on the other, but it is also crucial to overcome the conflict potential or "trade-off" between targeting monetary stability and financial system stability itself.

\section{Integration of the Monetary and Financial System Stability Framework}

Empirical facts show that the macroeconomic stability achievements attained during the period of great moderation between 1987 and 2007 would not automatically isolate the global economy from the impact of crisis, which was generated by financial sector susceptibility. Therefore, central bank policy formulation should simultaneously evaluate the strategic role of monetary policy and the financial system. Dynamics during financial crises have shown that monetary policy needs to be further directed towards anticipating macroeconomic instability risk stemming from the financial system. This implies that healthy macroeconomic management should also consider financial system stability as the foundation to realise a sustainable macroeconomic environment. "There is no macroeconomic stability without financial stability".

Within this policy perspective, in order to strengthen the framework of monetary and financial system stability, the central bank must be more flexible and creative in responding to emerging uncertainties within the economy and to think beyond public perception. Such flexibility is not merely linked to the adjustment preference to control inflation and manage the macroeconomy on the one hand, and the role of financial system stability on the other, but it is also crucial to overcome the conflict potential or "trade-off" between targeting monetary stability and financial system stability itself. ${ }^{5}$ In this connection, policy implementation flexibility can be achieved

\footnotetext{
${ }^{5}$ The occurrence of a trade-off between reaching monetary and financial system stability depends on the type of shock (Geraats 2010). If the shock originates from the demand side, efforts to stabilise prices and the financial system will generally move simultaneously. Central banks may adjust the interest rate to cope with shocks in aggregate demand in a bid to stabilize not only the output gap, but also prices of goods and assets. Meanwhile, shocks stemming from the supply side tend to have
} 
through additional instruments (in this case macroprudential instruments) in addition to establishing a longer time horizon to reach the inflation target in order to accommodate output stabilization in the near term. In connection with the measures to overcome potential policy conflict, it is no less important to prioritize the policy goal, for example by setting price stability as the overarching policy goal.

Urgency to strengthen the monetary and financial system stability framework requires strong financial infrastructure along with an adequate examination and supervision function to support domestic market integration into an increasingly complex financial system. To that end, Borio (2003) emphasizes the need to strengthen the regulatory framework or macroprudential policy, thereby limiting the risks when the financial market confronts intense pressures for a protracted period of time, which may force real output within the economy to tumble.

Conceptually, macroprudential policy is a prudential regulation instrument aimed at enforcing financial system stability as a whole, instead of the individual wellbeing of financial institutions. Analogically, microprudential policy is a prudential regulation instrument intended to maintain the health of individual financial institutions.

Macroprudential policy seeks to develop, oversee and deliver appropriate policy responses to the financial system as a whole. It aims to enhance the resilience of the financial system and dampen systemic risks that spread through the financial system. (Group of Thirty 2010)

Therefore, macroprudential policy is used to prevent boom-bust cycles of credit supply and liquidity, which may lead to economic instability. With its role in terms of maintaining stable financial intermediation supply, macroprudential policy backs the monetary policy goal of maintaining price and output stability. ${ }^{6}$

In a later development and in line with the changing financial sector arrangement, especially in the post-2008/09 crisis period, many central banks have applied macroprudential policy instruments covering a broader scope. In this connection, several instruments previously better known as microprudential instruments (such as loan-loss provisioning requirements, or loan-to-value) or monetary instruments

a reverse effect on price and financial system stability. This happens, for instance, when shocks on the supply side move positively by suppressing inflation but lifting output. Under such conditions, expansive monetary policy will likely propagate asset prices bubbles.

${ }^{6}$ There are two important dimensions of macroprudential policy. First, the cross-section dimension, which shifts the focus of prudential regulation applied on financial institutions individually to the regulation system as a whole. The history of financial crises shows that most of such crises occurring around the world were not caused by problems at an individual bank, which subsequently infected the system as a whole. On the contrary, major crises in the past were caused by exposure to macro-financial instability conducted simultaneously by most actors within the financial system. Therefore, a more holistic view on the financial system and its correlation with the macroeconomy through various sides is urgently required. The second dimension is the time-series one, namely macroprudential policy that aims to restrain the risk of excessive procyclicality within the financial system. In this context, macroprudential policy should be specifically designed to eliminate, or at least mitigate, procyclicality. Principally, it is about how to encourage the financial system to prepare an adequate buffer when economic conditions improve, or when financial system instability generally occurs, and how to use that buffer during an economic slump. 
(such as reserve requirements) were also used to prevent systemic risk and to maintain financial system stability in the economic activity cycle. Such policy instruments are not focused on efforts to deal with risk at an individual bank. Therefore, these policy instruments could be categorized as policy instruments in a wider macroprudential perspective. Several macroprudential policy instruments used in a number of countries are presented in Table 7.3.

Strengthening the monetary and financial system stability framework requires appropriate monetary and macroprudential policy integration. As is known, the main goal of monetary policy is to maintain price stability. To attain this goal, central banks traditionally use the interest rate as their primary instrument. However, maintaining price stability is still not sufficient to guarantee macroeconomy stability, as a financial system with its procyclical behaviour triggers excessive economic fluctuations. Meanwhile, the goal of macroprudential policy is to guarantee financial system resilience as a whole in a bid to support financial intermediation for the economy as a whole. With its countercyclical role, macroprudential policy supports the goal of monetary policy in terms of preserving price and output stability.

The objectives achieved through monetary and macroprudential policies are mutually reinforcing. Steps to empower financial system resilience will also improve

Table 7.3 Macroprudential policy implementation in several countries

\begin{tabular}{l|l|l}
\hline Problem & Instrument & Countries \\
\hline $\begin{array}{l}\text { Leverage (procyclicality } \\
\text { potential) }\end{array}$ & $\begin{array}{l}\text { Risk-weighted adjustment of } \\
\text { capital regulations }\end{array}$ & $\begin{array}{l}\text { India, Indonesia, Malaysia, } \\
\text { Estonia, Ireland, Portugal, } \\
\text { Norway }\end{array}$ \\
\cline { 2 - 3 } $\begin{array}{l}\text { Credit (Correlation and } \\
\text { characteristics of borrowers, } \\
\text { pressure over macro stability) }\end{array}$ & $\begin{array}{l}\text { Application of capital to } \\
\text { risk-weighted asset ratio } \\
\text { provisioning (provisions for } \\
\text { certain credit) }\end{array}$ & $\begin{array}{l}\text { India, Bulgaria, Croatia, } \\
\text { Estonia, Australia }\end{array}$ \\
\cline { 2 - 3 } & $\begin{array}{l}\text { Limitations of loan-to-value } \\
\text { ratio on certain sectors (with } \\
\text { potential bubbles) }\end{array}$ & $\begin{array}{l}\text { China, Hong Kong, Korea, } \\
\text { Singapore, Malaysia, } \\
\text { Thailand, Bulgaria, Norway, } \\
\text { Portugal, Rumania }\end{array}$ \\
\hline \multirow{2}{*}{$\begin{array}{l}\text { Liquidity (risk potential on } \\
\text { certain aspects) }\end{array}$} & $\begin{array}{l}\text { Credit limitations to certain } \\
\text { sectors (such as property, } \\
\text { credit cards) }\end{array}$ & $\begin{array}{l}\text { Korea, Malaysia, the } \\
\text { Philippines, Singapore, } \\
\text { Thailand, Rumania }\end{array}$ \\
\cline { 2 - 3 } & $\begin{array}{l}\text { Changes in reserve } \\
\text { requirements across the board } \\
\text { or specific targets }\end{array}$ & $\begin{array}{l}\text { China, India, Indonesia, } \\
\text { Korea, Malaysia, Finland, } \\
\text { Estonia }\end{array}$ \\
\cline { 2 - 3 } & $\begin{array}{l}\text { Application of loan-to-deposit } \\
\text { ratio }\end{array}$ & $\begin{array}{l}\text { India, Korea, the Philippines, } \\
\text { Singapore }\end{array}$ \\
\hline China, Korea, Indonesia \\
\hline
\end{tabular}

Source Borio and Shim (2007), Hannoun (2010), Group of Thirty (2010) 


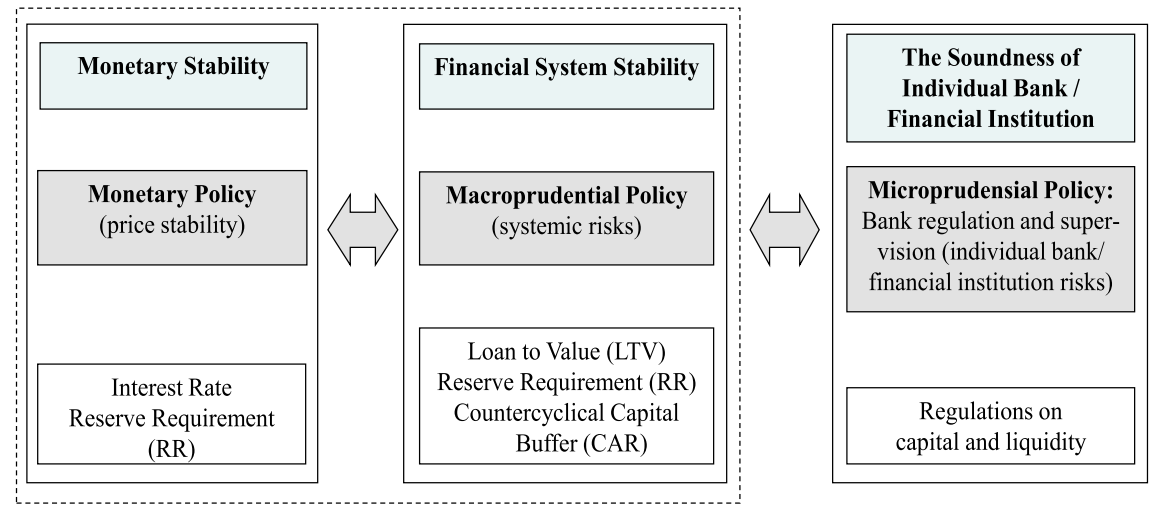

Fig. 7.2 Integration of monetary-macroprudential policy. Source Bank Indonesia

monetary policy, including protecting the economy from sharp fluctuations within the financial system. On the other hand, macroeconomy stability will reduce financial system vulnerability due to procyclicality. In general, therefore, the interest rate may not need to move at a magnitude usually required in times of no policy integration or coordination. Meanwhile, macroprudential policy affects credit supply and, consequently, monetary policy transmission. The effectiveness of policy coordination definitely relies on the macroeconomic environment, financial conditions, the intermediation process as well as the level of capital and assets in the banking system. Hence, it is not realistic to expect the combination of monetary and macroprudential policy to be fully capable of eliminating economic cycles. The main goal of such policy integration is to moderate cycles and bolster financial system resilience at a macro scale.

Improvement of the monetary and financial system stability framework, through monetary and macroprudential policy integration, is illustrated in Fig. 7.2.

Such monetary and macroprudential policy can be described as follows. Macroprudential policy aims to tighten capital and the liquidity requirement during an economic upswing, thus compelling banks to rein in credit growth in an effort to build up resilience and anticipate a future economic slump. In this condition, efforts to maintain banking sector resilience will simultaneously underpin the monetary policy goal of stabilising credit supply. Therefore, the objective of such macroprudential policy, with its countercyclicality, will synergize with the goal of monetary policy, namely to reduce excessive economic fluctuations (Fig. 7.3).

Several conditions are required to make the integration of monetary and macroprudential policy run well. Firstly, there is a need to understand the framework of the linkages among monetary policy, macroprudential and microprudential policies. This is to take into account the conflict potential to reach the objective of the policy. That is why the use of an instrument mix or adding new instruments could be considered as the right alternative move. Secondly, there is a need to understand the workings of monetary and macroprudential policy transmission in terms of affecting economic 


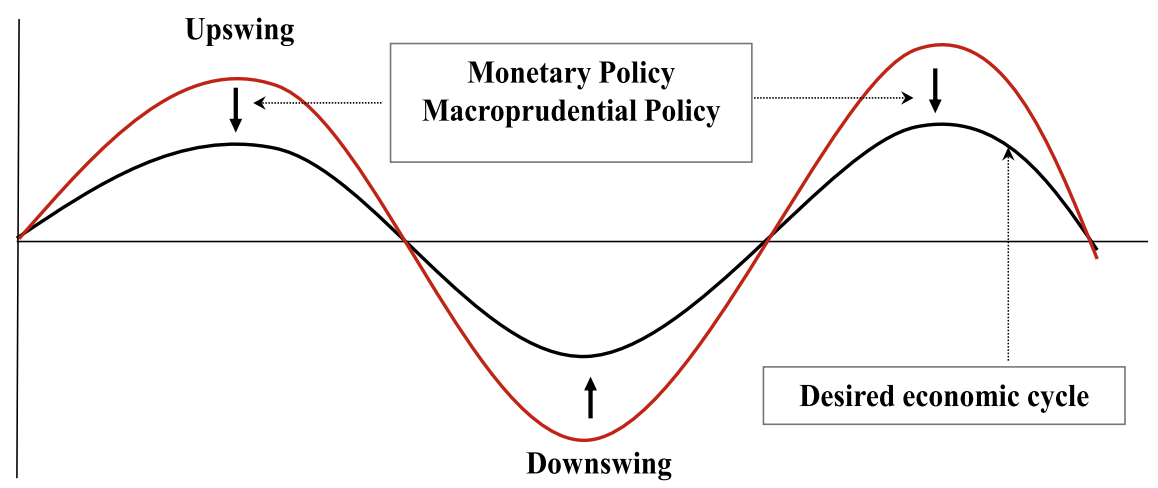

Fig. 7.3 Monetary and macroprudential policy to dampen procyclicality. Source Bank Indonesia

activity. This requires a more integrated analytical framework, especially when evaluating the important role of the financial sector. Thirdly, there is a need to measure the right risk behaviour indicators to support risk system monitoring. Measuring the risk indicators in addition to supporting the right monitoring system will also strengthen the analysis of the transmission mechanism through the risk-taking channel.

\section{Policy Instrument Mix as a Key Strategy}

\section{The Objectives}

On an ideal financial market, the central bank typically relies on a single instrument to reach the monetary policy goal. In reality, however, market imperfections are always present, such as those relating to banking structure and soundness, the distribution gap in market liquidity and excessive market fluctuations. Imperfections force the employment of an instrument mix and wider operational procedures to support the effectiveness and efficiency of monetary policy implementation.

Empirically, the variations when employing an instrument mix are based on several considerations (Balino and Zamalloa 1997). First, to secure the achievement of monetary management in terms of weathering the turbulence that distorts the supply and demand of banking reserves. Second, to adapt to instrument and operational procedures in line with institutional constraints affecting the work of an instrument. Third, to gain the objectives of other policies deemed crucial and supportive to the work of the monetary policy transmission mechanism. Fourth, to adjust to the macroeconomic policy environment, especially to the type of monetary and exchange rate regime. Referring to the Tinbergen rule, it is said that for each and every policy target there must be at least one policy tool, therefore the application 
of instrument mix is deemed necessary in case of a change in economic conditions along with the corresponding challenges, which also support the policy objective enlargement targeted by policymakers.

In this connection, besides the availability of several policy instruments, of most significance is how to mix or coordinate the application of the instruments to raise policy effectiveness in terms of supporting general economic development. This is to consider that each instrument has its own unique timing and magnitude characteristics. In a later development, the application of an instrument mix has become a trending practice at many central banks. In this regard, the type of mix is not merely limited to monetary policy instruments, but also tends to include a mix of monetary policy instruments and other policy instruments, such as those of macroprudential policy. With a different policy umbrella, it is not a simple task to formulate the correct kind of mix.

\section{Policy Mix Variations}

As previously mentioned, the complexity of problems generated by the $2008 / 09$ global financial crisis has raised awareness that the role of the financial system should be taken into account in monetary policy formulation. For instance, the decision has to be made as to whether or not monetary policy is required in response to asset price developments that potentially lead to financial market imbalances. Apart from the growing debate over such an issue and despite that monetary policy is crucial in terms of controlling financial sector imbalances, this does not mean that asset price stability, for instance, should be an explicit target of monetary policy. This is to consider that monetary policy itself is not capable of controlling asset prices, especially when asset price speculation contributes to surging prices, thereby precipitating an extremely high return on assets. Under such conditions, any changes in the interest rate would fail to affect investors' portfolios, especially against those investments within the financial market. An across-the-board interest rate hike would 'overkill' the economy as a whole.

Therefore, monetary policy requires additional supporting instruments to control the surge in asset prices on the financial market. In this case, countercyclical macroprudential policy instruments could be utilised to overcome procyclicality and backup monetary policy to achieve macroeconomic stability. One example of a macroprudential instrument that would complement the interest rate in terms of managing asset prices is the Loan-to-Value (LTV) ratio, namely the ratio of money borrowed on a property to the property's fair market value, which aims primarily to fend off asset bubbles in the housing sector. To that end, LTV is set at a certain limit (for instance at a maximum of $80 \%$ ), which is generally considered as a norm or a reference in credit expansion for real estate development and is safe enough from a macroprudential point of view.

An instrument mix is also applicable to quell the complexity of problems accompanying the prolonged economic recovery in advanced countries, which propels an 
influx of foreign capital into emerging countries. In certain countries, such as China, India and Indonesia, the foreign capital inflow phenomenon complicates efforts to oversee soaring liquidity on domestic financial markets. Greater excess liquidity could potentially accelerate credit growth and compound inflationary pressures on the monetary side. Due to such complexity in the form of distortions in both external and internal imbalances, the role of the interest rate instrument turns out to be extremely limited.

An interest rate hike as a measure to control economic liquidity by a central bank would eventually be offset by the significant force of foreign capital inflows, which leaves efforts to oversee macroeconomic stability ineffective. This offsetting phenomenon repeats itself as a vicious circle of capital inflows. Under such conditions, monetary policy transmission taken through the interest rate channel would face constraints, especially over the workings of the term structure interest rate hypotheses. In this case, the development of monetary aggregates, including credit, tends to be inelastic to interest rate performance. For that reason, if the interest rate is used as a monetary instrument, the complexity of the problems requires the use of other instruments (non-interest rate) as a backup to optimally reach the goal of monetary policy.

There are several examples of an instrument mix that support the role of the interest rate, for instance the reserve requirement (RR). The modification of RR in domestic exchange is often seen as a part of those instruments to implement monetary and exchange rate policy. Evaluating the phenomenon of how developing countries responded to rapid inflows of foreign capital, the attention has been focused more on the use of RR to moderate the financial cycle. Adjustments to RR could be used to supplement or replace the use of an interest rate instrument to control the impact of credit on the economy. In a later development, a number of countries also applied RR to their foreign exchange based financing provided by financial institutions. In this case, macroprudential issues are closely related with currency mismatch and vulnerability of foreign exchange liquidity within the banking system, which may also be caused by the financing scheme itself. Additionally, RR variation has been applied based on a specific consideration. In general, the application of RR variation is for macroprudential purposes under a condition where the credit market is segmented and dominated by intermediation institutions, which is tightly regulated. Although the same impact may be generated from the application of the interest rate instrument, the use of RR can be classified as a more direct way to influence banks' funding costs and capacity in triggering financial market imbalances.

The forms of instrument policy mix applied by many central banks are also varied. One form is through reliance on foreign exchange market intervention, which is generally related to accumulating foreign exchange reserves in a bid to manage the external balance. Under a flexible exchange rate regime, central banks intervene on the foreign exchange market to dampen exchange rate volatility and/or to accumulate foreign exchange reserves. This has been evidenced by foreign exchange reserve assets growing with rapidity over the past decade. Yet, foreign exchange reserve accumulation bears its own costs. On one hand, foreign exchange reserves can be seen as a macroprudential instrument to enhance resilience during an episode of 
financial market distress. On the other hand, however, persistently large foreign capital inflows along with a surge in central bank foreign assets almost always enlarge the banking system balance, which would eventually lead to a credit and asset price boom, culminating in a crisis.

The use of macroprudential instruments thus raises a question over how such instruments connect with interest rate policy; whether as a complement or a substitute. It is understood that the use of both instruments is a tactical way to influence financial sector conditions. Macroprudential instruments work by influencing financial sector incentives and resilience and directly impact the monetary policy transmission mechanism. Such instruments work by either strengthening or weakening policy repercussions, which are ultimately reflected in the accessibility and the cost of borrowing faced by debtors (private and public). From this point of view, such macroprudential instruments fall into the complementary category. For instance, in terms of weathering intense inflationary pressures, rapidly growing credit and soaring asset prices, central banks have a proclivity to tighten monetary policy and employ additional countercyclical instruments. In this case, both interest rate policy and macroprudential policy will mutually strengthen one another to tighten financial sector conditions.

As both will eventually affect the accessibility and cost of borrowing, however, such instruments could also be classified as substitutes. Specifically, interest rate and macroprudential instruments may be adjusted to simultaneously tackle shocks in the macroeconomy and financial sector. For instance, central banks could either raise the interest rate or RR. The interest rate magnitude and RR ratio would be determined depending on the proximity of the macroeconomy with financial stability, and the relative effectiveness of such instruments. For example, a dilemma emerges when inflationary pressures are weak, while credit and asset prices accelerate. One of the possible scenarios of using an instrument mix is the use of interest rate policy to fight inflation, while RR policy is instituted to confront financial system stability risks. Based on such an interpretation, the interest rate may not be changed due to weak inflationary pressures, while the RR could be raised to smother excessive credit growth and a potential asset price hike. The advantage is that an increase in RR may not attract significant capital inflows, unlike an interest rate hike. However, whether the application of this scenario is sufficiently optimal requires further analysis.

\section{Technical Aspects of Implementation}

When implementing the policy instrument mix, several aspects require consideration in order for optimal performance, including: (i) the signals necessary to elicit a response; (ii) response characteristics; (iii) timing of implementation and 
procyclicality; (iv) effectiveness and calibration of policy measures; and (v) policy communication. ${ }^{7}$

\section{Signals Necessary to Elicit a Response}

Within a forward-looking policy perspective, the policy response should be directed towards anticipating signals related to distortions of future macroeconomic balance. In this case, a policy response may not be necessary in the case of temporary shocks. ${ }^{8}$ The lessons gleaned from past crises revealed that a number of indicators and analyses can be used as policy response guidance through their advantage to detect resilience, imbalances and systemic risks. Examples of such indicators include financial system resilience, macroeconomic resilience and systemic risk. Generally, such indicators are predominantly set within an early warning system framework.

Therefore, the accuracy of the policy response will depend highly on the performance of those indicators in predicting possible imbalances. Although theoretically such indicators may be easily constructed, the performance of empirical models and analyses in terms of predicting imbalances, or through an early warning system framework, remains unconvincing. For instance, it is difficult to observe the exact timing and magnitude of credit growth that can be sensitive to economic vulnerability, bearing in mind that rapid credit growth is also required within a fast changing economy due to the profit-taking opportunities which lead to financial deepening, as experienced in various Latin American countries. Thereby, there is an urgency to have more systematic research and better understanding of systemic risk characteristics and their correlation to the benefits from a macroeconomic perspective.

\section{Response Characteristics}

When formulating a macroprudential policy response, one of the crucial issues is whether the response will apply a rule versus discretion. Similar to monetary policy, the trade-off between a rule versus discretion is a constant. A rule provides certainty for market players and credibility to central banks. However, a rule that is too rigid undermines the flexibility to respond to both structural changes and uncertainties frequently occurring in the financial market.

On the other hand, discretion provides room for central banks to assess the macroprudential impact against the financial system and the economy and then to apply some adjustments towards the use of such approaches in addition to setting a judgment

\footnotetext{
${ }^{7}$ For further discussion on such issues, see Moreno (2011), Committee on the Global Financial System (2010), Barell et al. (2010) and Born et al. (2010).

${ }^{8}$ Based on several empirical studies, it is generally acknowledged that financial cycles have a lower frequency compared to business cycles (Borio 2012). However, under certain conditions, they might be relatively synchronous (Oman 2019).
} 
over the possibility of future policies to be taken. Discretion definitely triggers uncertainties over possible future policies, which would unquestionably compel prudence amongst market players by maintaining liquidity and a capital ratio at a higher level than required. Consequently, banks would become less efficient and charge the cost of capital to borrowers, creating a high cost of credit in the economy. Discretion may also lead to forbearance, especially when confronted with a difficult or unpopular decision to be taken. Nonetheless, such discretion policy bears a legal consequence on the central bank. Considering the strengths and weaknesses of both rules and discretion, the decision model could incorporate rule-constrained discretion.

\section{Timing of Implementation and Procyclicality}

It is important to take into account the timing of policy application during an economic cycle, partly because a macroprudential regulation is often procyclical. ${ }^{9}$ A number of other issues pertaining to the application of a macroprudential framework are countercyclical as follows.

1. Relates to how much weight is given to measures to stabilize an economic cycle (e.g. GDP) compared to measures to manage the financial sector cycle (e.g. credit and asset prices). One fundamental issue is whether with the rapid innovation found in the financial sector, the policymaking authorities are able, in a timely fashion, to extract the financial sector cycles (e.g. "excessive" credit growth, "inflated" asset prices, "abundant" liquidity) from the variations in the normal cycle and long-term trends.

2. Relates to who should assess the cycle (the public sector or the private sector)? As is known, economic cycles are unobservable and methods to estimate them are fraught with numerous uncertainties. Therefore, a diversity of opinions is likely to occur. One of the solutions for policymaking authorities is to rely on a group of independent experts like the approach taken in Chile (to determine the long-term trend of the country's GDP and copper prices) when implementing the fiscal rule.

3. Relates to the timeliness of action taken. Lateness in taking action may have implications on actions that are more procyclical than countercyclical.

\footnotetext{
${ }^{9}$ For example, the provision on the removal of allocation for productive assets (the loan-loss provision) tends to decrease while the NPL ratio also tends to fall during the expansionary period. The financial market itself is procyclical as risk distribution tends to narrow during the expansionary phase and dilate, sometimes drastically, during the contractionary phase. From a risk-management perspective, policy instruments should ideally be applied as early as possible by considering the risks that may appear in the event of deteriorating economic conditions (based on observations of economic cycles). Some opinions suggest that measures should be countercyclical, i.e., tightening during periods of expansion and loosening during periods of contraction. In response to the crisis, the Basel Committee on Banking Supervision took a number of measures (in the context of Basel III) to reduce procyclicality. These measures include (i) assessing and mitigating the effect of cyclicality of minimum capital requirements; (ii) encouraging forward-looking provisioning; (iii) adopting a regulatory framework for capital conservation and countercyclical buffer; and (iv) introducing a minimum leverage ratio.
} 
4. Relates to whether the prudential ratio should remain constant or move with the cycle. A solution would be to set a wide enough range of stability for, say, the targeted GDP. Thus, the change in provisioning to manage the cycle is adjusted only when the target is outside the corridor. In this regard, judicious decisions are critical to complement the existing formal rule or to calibrate policy measures.

\section{Effectiveness and Calibration of Policy Measures}

The effectiveness a policy instrument will affect the calibration of the selection of policy measures that are deemed appropriate. In contrast to the analysis of monetary policy transmission, there has been no theoretical macroprudential policy framework developed or robust empirical results to guide the calibration. With the uncertain impact of a macroprudential policy instrument, the policymaking authorities need to be pragmatic in the use of the instrument. This is certainly not easy in the absence of a theoretical foundation and empirical research that describes how policy measures might be adjusted when calculating potential risks that could arise.

A study on the results of the calibration of macroprudential policies in OECD countries (Barrell et al. 2010) indicates that, in general, macroprudential policies can be used to address the macroeconomic risks confronting banks and simultaneously reduce the probability of a crisis happening. Antipa et al. (2011), using the UK and U.S. as case studies, also concluded that macroprudential policies would have been particularly effective for smoothing the credit cycle and preventing the global financial crisis from bringing about deeper ramifications. Beyond these findings, one particular thing that is important to note is the need for a compromise to enable a country to make adjustments to the application of macroprudential instruments considering that adjustments to instruments or regulations may also lead to the incurrence of costs, including an increase in funding costs and margins, thus adversely impacting an increase in economic activity. Thus, policy application needs to be performed at a proper dosage in order to align the costs and benefits thereof with the risk control expected.

\section{Policy Communication}

Communication in the context of monetary policy and macroprudential integration is crucial and by no means a simple challenge. Firstly, conveying a message to the market about the dangers of the growing imbalance in the financial sector during an economic boom is difficult because such a message would be very unpopular in the midst of market optimism. A monetary policy response in the form of higher interest rates when there are no immediate inflationary pressures is politically and economically hard to accept because the central bank could be perceived as jeopardizing growth and the interests of the people. Therefore, persuasive communication to the public concerning the importance of long-term stability is very much required. The communication strategy for normal conditions would be unusable under conditions 
of excessive optimism. The communication of monetary policy needs to adjust to the ongoing dynamics of the financial system. Here, the role of macroprudential policy that is rule-based in supporting monetary policy makes the central bank's task easier. With such support, monetary policy only plays the role of transmitting signals rather than directly controlling the growing risks in the financial sector. Secondly, future economic uncertainties, which are very high, especially during the turning points of economic cycles, pose a unique challenge for policy communication.

\section{Conclusion and Implications}

In this paper we have discussed various underlying aspects of the linkage between monetary and financial stability and a number of central issues that still need to be analysed further, particularly in relation to the practical significance of risk-taking behaviour in reshaping the workings of the monetary policy transmission mechanism. The discussion leads us to the understanding that there are several strategic and tactical challenges facing central banks in terms of designing policy strategy to integrate the monetary and macroprudential policy framework, especially to meet the dual objectives of monetary stability (price) and financial stability. Given the fact that the nexus between monetary and financial stability, whether they are substitutes or complements, is still an open debate, it is important to draw implications, especially related to the central bank's policy mandate.

\section{Adjustment of Mandate and Its Consequences on Policy Governance}

Learning from the crisis, when formulating a post-crisis monetary policy strategy the central bank should increasingly strengthen its function in terms of stabilizing the financial system to ensure macroeconomic stability. The shifting or emphasizing of the central bank's mandate to maintain financial system stability has consequences on policy governance. Moving away from the generally understood format of monetary policy governance, as in the application of ITF, the format of policy governance for financial system stability is not yet fully understood. Adoption of financial system stability as a major or additional aspect of the responsibilities of the central bank could give rise to complications in the format of central bank policy governance. Hence, it is by no means an easy feat to design a central bank's mandate to simultaneously maintain the stability of prices and the financial system.

There are several underlying reasons for complications in central bank policy governance (Crockett 2010). Firstly, there is no firm and quantified understanding of the objectives of financial stability as understood in the objectives of price stability. Thus, there has been no benchmark on how to assess the central bank's success 
in fulfilling its responsibility to maintain financial stability. Secondly, the responsibility for maintaining financial system stability is essentially multidimensional. The scope of such responsibility starts from prudential supervision, the establishment of policies to prevent systemic risks to liquidity support in the financial market and individual financial institutions. In this regard, there is no clear governance model that accommodates differences in the characteristics of each of these steps. Thirdly, decisions related to financial system stability tend to be politically sensitive, as compared to monetary stability. This makes it difficult to align the interest to maintain independence with the response to the existing political environment. In that case, the toughest challenge faced by central bank in an effort to maintain independence is how action taken by the central bank, especially in areas outside the central bank's mandate, could finally be officially accepted and legitimized by the government or parliament.

In relation to this way of thinking, one of the issues raised is how to place a mandate to maintain financial system stability in the monetary policy framework. One of the alternative monetary policy formats that can be drawn up is to continue using price stability as the main element that determines the monetary policy response. The substance of price stability has expanded, however, to accommodate financial stability indicators and has a broader forward-looking horizon.

Another alternative policy format is to establish strengthening financial system stability as one of the mandates of monetary policy, in addition to maintaining price stability. In respect to this, Svensson (2010) asserts that there is a close linkage between the achievement of monetary stability and financial system stability. Financial system stability directly affects the financial market and financial market conditions will affect the effectiveness of the monetary policy transmission mechanism. Therefore, a financial market in trouble may affect real economic activities drastically, as indicated by the occurrence of financial crises. Meanwhile, monetary policy affects bank balance sheets and asset prices, which in turn affect financial system stability. Despite being interrelated, however, both have conceptual differences in terms of the objectives, instruments used and authorities responsible. Thus, it is unreasonable to refer to the achievement of financial stability as part of the monetary policy mandate. ${ }^{10}$

Hence, some views suggest that price stability should be the overarching objective of monetary policy ${ }^{11}$. Meanwhile, the substance of financial system stability, particularly in its relation to macroprudential policies, should be calculated carefully and efforts should be made to prevent the achievement of policy goals that are too ambitious, for example through overregulating the development of asset prices and credit growth. One initial step to address this situation is through the use of macroprudential instruments to address the apparent imbalance in credit and asset markets.

\footnotetext{
${ }^{10}$ Beyond that, as argued by Blinder (2010) and Nyberg (2010), such conceptual differences do not negate the possible gains of accountability, which are vast, for maintaining financial system stability by the central bank.

${ }^{11}$ See Svensson (2010), Hannoun (2010), and Jordan (2010).
} 
In the future, in line with the policy practice of using various macroprudential instruments along with monetary instruments, a more appropriate policy mandate could be formulated on the basis of past experiences.

\section{Mandate for the Implementation of Macroprudential and Microprudential Policies}

In carrying out its function to achieve and maintain financial system stability, a central bank requires supporting instruments in the form of macroprudential and microprudential supervision. Macroprudential supervision refers to the process of managing the overall soundness of the financial system, which is achieved through a series of behavioural analyses of the financial sector and financial market conditions. This management process is implemented by designing policy architecture and responses to ongoing financial system conditions. Meanwhile, microprudential supervision is the process of individually managing the soundness of financial institutions, which is carried out through supervision and regulation that is expected, in aggregate, to create continuity and stability in the financial system and provide consumer protection.

The crisis also showed that close coordination between microprudential supervision and macroprudential supervision in formulating appropriate and expeditious policies at crucial times is required. Macroprudential supervision is directed at the activities of financial institutions, both banks and nonbanks, which have a significant influence on both the financial market and the financial system. According to macroprudential supervision, macro indicators are monitored as a means to anticipate and mitigate various anticipated risks that may threaten the stability of the financial system and real economy as a whole. In addition, monitoring macroprudential conditions may also provide information on systemic risks and mitigate the propagating effects of disturbances occurring at financial institutions that may interfere with the business cycle. Information acquired from macroprudential supervision will assist policymakers as to whether it is necessary or not to rescue a financial institution that is experiencing a lack of liquidity. In practice, the authority carrying out the monitoring of macroprudential conditions requires immediate and forthcoming access to information, micro data and unimpeded official authority to acquire any additional data as required.

Given the linkages between microprudential policy and macroprudential policy, does this also mean that the central bank also needs to be given the responsibility to implement microprudential policies? Those arguing for or against the need for central banks to implement microprudential policies are still continuing their debates to this day. Substantively, it can be understood that the most important element for the effectiveness of central banks in maintaining financial system stability is the continuity of the flow of exchange and the quality of information between microprudential and macroprudential supervisory agencies, given that the functions of both agencies are 
complementary. In light of this, the feasibility of information exchanged depends on the institutional framework of the agencies, their habits and human factors.

Thus, if the central bank is not mandated to implement microprudential policies, then close coordination between the central bank and the competent authorities in the microprudential supervision sector is absolutely necessary. In other words, coordination is as necessary as maintaining consistency and harmony amongst the achievement of the goals of monetary, macroprudential and microprudential policies. In this case, macroprudential policy has an extremely vital role both in supporting monetary policy in maintaining macroeconomic stability and microprudential policy. Macroprudential policy in a narrower dimension requires the consistent use of microprudential instruments while macroprudential policy in a broader sense requires consistent monetary policy.

The aforementioned view has very significant ramifications on the institutional mandate of Bank Indonesia, whereby the banking supervision function was separated from Bank Indonesia and turned over to a new institution, namely the Financial Services Authority (FSA). The paradigm that monetary policy requires the support of macroprudential policy implies that the two cannot be separated in order for both to operate effectively.

After the establishment of FSA, the macroprudential policy framework shall inevitably involve two institutions, that is, Bank Indonesia and the FSA, which is authorized to regulate and supervise microfinance institutions. Bank Indonesia has the ability to assess macroeconomic risks and global financial market developments. Meanwhile, the FSA has information about individual financial institutions. Therefore, in order for the system to function properly, there must be a mutual exchange of information between Bank Indonesia and the FSA. ${ }^{12}$ The FSA must provide all information relating to the monitoring of individual risks whereas Bank Indonesia has access to macroprudential assessments that must be submitted to the FSA to be implemented at an individual level.

\section{References}

Altunbas, Yener, Leonardo Gambacorta, and David Marques-Ibanez (2009), “An Empirical Assessment of The Risk Taking Channel", paper presented on the BIS/ECB Workshop on "Monetary Policy and Financial Stability"-Basel.

Antipa P., Mengus E. and Mojon B. (2011), "Would Macro-prudential Policies Have Prevented the Great Recession?" Banque de France mimeo.

\footnotetext{
12 Arguments for and against the need for central banks to implement microprudential policies are still continuing to develop to this day. Substantively, it can be understood that the most important element for the effectiveness of central banks in maintaining financial system stability is the continuity of the flow of exchange and the quality of information between microprudential and macroprudential supervision, given that the two have complementary functions. Pertaining to this, feasible information depends on institutional form, habits and the human factor. Thus, if a central bank is not mandated to implement microprudential policies, close coordination between the central bank and the competent authorities in the microprudential supervision sector is absolutely necessary.
} 
Baliño, Tomás J. T. and Lorena M. Zamalloa (1997), "Instruments of Monetary Management: Issues and Country Experiences", International Monetary Fund.

Barrell, R., Davis, E.P., Karim, D. and Liadze, I. (2010), "Calibrating Macroprudential Policy", Discussion Paper 354, National Institute of Economic and Social Research.

Bernanke, B.S. and M. Gertler (1999), "Monetary Policy and Asset Volatility", Federal Reserve Bank of Kansas City Economic Review, 84(4), pp. 17-52.

Blinder, Allan S. (2010), "How Central Should the Central Bank Be?" Princeton University CEPS Working Paper No. 198, January.

Borio, Claudio, Craig Furfine and Philip Lowe (2001), "Procyclicality of the Financial System and Financial Stability: Issues and Policy Options", Bank for International Settlements (BIS) Paper No. 1.

Borio, C. (2012). The financial cycle and macroeconomics: What have we learnt? BIS Working Papers No 395. Dec.

Borio, Claudio (2003), "Towards a Macroprudential Framework for Financial Supervision and Regulation?” BIS Working Paper No. 128, December.

Borio, Claudio and Ilhyock Shim (2007), "What Can (Macro-)Prudential Do to Support Monetary Policy?” BIS Working Paper No. 242, December.

Borio, Claudio and Haibin Zhu (2008), "Capital Regulation, Risk Taking and Monetary Policy: A Missing Link in the Transmission Mechanism", BIS Working Paper No. 268, December.

Born, Benjamin, Michael Ehrmann and Marcel Fratzscher, (2010), "Macroprudential Policy and Central Bank Communication", the European Central Bank Working Paper, September version.

Committee on the Global Financial System (2010), "Macroprudential Instruments and Frameworks: A Stocktaking of Issues and Experiences", CGFS Papers No 38, May.

Craig, R. Sean, Davis, E3 Philip and Garcia Pascual, Antonio, (2006), "Sources of Pro-cyclicality in East Asian Financial Systems", Economics and Finance Discussion Papers, School of Social Sciences, Brunel University.

Crockett, Andrew (2010), "What Have We Learned in the Past 50 Years about the International Financial Architecture?" Address at Symposium to mark the 50th Anniversary of the Reserve Bank of Australia.

De Nicolò, Gianni, Giovanni Dell'Ariccia, Luc Laeven, and Fabian Valencia (2010), "Monetary Policy and Bank Risk Taking", IMF Staff Position Note, SPN/10/09, July.

Geraats, Petra M. (2010), "Price and Financial Stability: Dual or Duelling Mandates?” University of Cambridge.

Group of Thirty (2010), "Enhancing Financial Stability and Resilience: Macroprudential Policy, Tools, and Systems for the Future"

Goldfajn, Ian and Poonam Gupta (2002), "Overshootings and Reversals: The Role of Monetary Policy", in Leonardo Hernandez and Klaus Schmidt-Hebbel (Eds.), Banking, Financial Integration, and International Crises, Bank of Chile.

Hannoun, Hervé (2010), "The Expanding Role of Central Banks Since The Crisis: What are The Limits?" Speech at the 150th Anniversary of the Central Bank of the Russian Federation, BIS.

Issing, Otmar (2003), "Monetary and Financial Stability - Is There a Trade-Off?" Speech at the Conference on "Monetary Stability, Financial Stability and the Business Cycle", Bank for International Settlements, Basel.

Jordan, Thomas J. (2010), “A Changing Role for Central Banks?", Speech at the Welcome Event Master of Banking and Finance, St. Gallen, September, BIS.

Mishkin, F. S., 1990. Asymmetric Information and Financial Crises: A Historical Perspective. NBER Working Paper, Volume 3400

Mishkin, Frederic S. (2009), "Is Monetary Policy Effective during Financial Crises", American Economic Review, 99 (2).

Moreno, Ramon (2011), "Policymaking from A “Macroprudential” Perspective in Emerging Market Economies", BIS Working Papers No 336, January. 
Nier, Erlend and Lea Zicchino (2008), "Bank Losses, Monetary Policy and Financial StabilityEvidence on the Interplay from Panel Data," IMF Working Papers 08/232, International Monetary Fund.

Nijathaworn, Bandid (2009), "Rethinking Procyclicality: What is It Now and What Can be Done", Paper presented at BIS/FSI-EMEAP High Level Meeting, 30 November 2009, Tokyo, Japan.

Nyberg, Lars (2010), "After the Crisis - New Thoughts on Monetary Policy", Speech at Nordea, Stockholm, Sveriges Riksbank.

Oman, W. (2019). The synchronization of business cycles and financial cycles in the Euro Area. International Journal of Central Banking, 15(1), 327-362.

Schwartz, Anna J. (1995), "Why Financial Stability Depends on Price Stability”, Economic Affairs, Volume: 15 Issue: 4.

Svensson, Lars E.O. (2010), "Inflation Targeting after the Financial Crisis", Speech at the International Research Conference Challenges to Central Banking in the Context of Financial Crisis, Mumbai, February.

Open Access This chapter is licensed under the terms of the Creative Commons AttributionNonCommercial-NoDerivatives 4.0 International License (http://creativecommons.org/licenses/bync-nd/4.0/), which permits any noncommercial use, sharing, distribution and reproduction in any medium or format, as long as you give appropriate credit to the original author(s) and the source, provide a link to the Creative Commons license and indicate if you modified the licensed material. You do not have permission under this license to share adapted material derived from this chapter or parts of it.

The images or other third party material in this chapter are included in the chapter's Creative Commons license, unless indicated otherwise in a credit line to the material. If material is not included in the chapter's Creative Commons license and your intended use is not permitted by statutory regulation or exceeds the permitted use, you will need to obtain permission directly from the copyright holder.

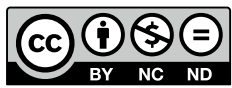

